\title{
Efek Learning Management System Berbasis Google Classroom dan Minat Belajar Terhadap Hasil Belajar Ekonomi Siswa
}

\author{
Septenti Yuti Yulfianti*, Retno Mustika Dewi \\ Fakultas Ekonomi dan Bisnis, Universitas Negeri Surabaya \\ *Corresponding Author. Email: septentiyuti@gmail.com
}

\begin{abstract}
The study aims to analyze the effect of google classroom based Learning Management System (LMS) and interest in learning on student learning outcomes. The type of this research is quantitative research with descriptive statistical methods. Research subjects were senior high school 3 Sidoarjo 10 social class, totaling 75 respondents. The instrument used in this study was a questionnaire used to measure the variable google classroom (X1) and interest in learning (X2). On the learning outcomes (Y) variable measured by the odd semester grade senior high school 3 Sidoarjo 10 social class. The data analysis technique used multiple linear regression analysis. The results of the study indicate that1) There is an effect of Learning Management System based of google classroom on students economic learning outcomes 2) There is an influence of interest in learning on student learning outcomes and 3) There is the influence of Learning Management System based google classroom and interest in learning on student learning outcomes. The conclusion of this study is that The Learning Management System based on Google Classroom simultaneously affect learning outcomes.
\end{abstract}

\begin{abstract}
Abstrak: Penelitian ini bertujuan untuk menganalisis pengaruh Learning Management System (LMS) berbasis google classroom dan minat belajar terhadap hasil belajar ekonomi siswa. Jenis penelitian ini adalah penelitian kuantitatif dengan metode statistik deskriptif. Subyek penelitian ini adalah kelas 10 IPS SMA Negeri 3 Sidoarjo yang berjumlah 75 siswa. Instrumen yang digunakan pada penelitian ini adalah kuisioner yang digunakan untuk mengukur variabel google classroom (X1) dan minat belajar (X2). Pada variabel hasil belajar (Y) diukur dengan nilai semester gasal kelas 10 IPS SMA Negeri 3 Sidoarjo Jawa Timur. Teknik analisis data menggunakan analisis regresi linier berganda. Hasil dari penelitian ini menunjukkan bahwa; 1) Terdapat pengaruh Learning Management System (LMS) berbasis google classroom terhadap hasil belajar ekonomi siswa; 2) Terdapat pengaruh minat belajar terhadap hasil belajar ekonomi siswa; dan 3) Terdapat pengaruh Learning Management System (LMS) berbasis google classroom dan minat belajar terhadap hasil belajar ekonomi siswa. Kesimpulan dari penelitian ini adalah Learning Management System (LMS) berbasis google classroom dan minat belajar secara bersamasama berpengaruh terhadap hasil belajar ekonomi siswa SMA Negeri 3 Sidoarjo Jawa Timur.
\end{abstract}

\section{Article History}

Received: 08-03-2021

Revised: 21-04-2021

Accepted: 03-05-2021

Published: 07-06-2021

\section{Key Words:}

LMS, Google

Classroom, Interest

in Learning,

Learning Outcomes.

\section{Sejarah Artikel}

Diterima: 08-03-2021

Direvisi: 21-04-2021

Disetujui: 03-05-2021

Diterbitkan: 07-06-2021

\author{
Kata Kunci: \\ LMS, Google Classroom, \\ Minat Belajar, Hasil \\ Belajar.
}

How to Cite: Yulfianti, S., \& Dewi, R. (2021). Efek Learning Management System Berbasis Google Classroom dan Minat Belajar Terhadap Hasil Belajar Ekonomi Siswa. Jurnal Kependidikan: Jurnal Hasil Penelitian dan Kajian Kepustakaan di Bidang Pendidikan, Pengajaran dan Pembelajaran, 7(2), 491-502. doi:https://doi.org/10.33394/jk.v7i2.3717

https://doi.org/10.33394/jk.v7i2.3717

This is an open-access article under the CC-BY-SA License.

\section{Pendahuluan}

Pandemi Covid-19 terjadi pada akhir tahun 2019, dimana negara yang pertama kali terjangkit yaitu negara Cina tepatnya di Kota Wuhan. Hingga sampai saat ini penyebarannya 
terus meluas. Keberadaan pandemi Covid-19 ini dampaknya banyak dirasakan di berbagai bidang. Tidak hanya pada bidang kesehatan saja, melainkan banyak berbagai bidang lain yang terkena imbasnya. Salah satunya yaitu bidang pendidikan. Pandemi Covid-19 banyak memberikan pengaruh yang signifikan pada kegiatan pembelajaran di seluruh belahan dunia (Rozi et al., 2021). Dampak dalam dunia pendidikan yaitu adanya dampak jangka pendek dan dampak jangka panjang. Dampak jangka pendek adalah belum terbiasanya orang tua dengan sistem pembelajaran jarak jauh. Terutama bagi orang tua yang bekerja. Selain itu berdampak pada keadaan psikologis peserta didik, yang dalam pembelajarannya tanpa dampingan guru secara langsung. Membuat peserta didik lebih kesulitan dalam pelaksanaan pembelajaran. Dampak jangka panjang dalam pendidikan dapat dilihat dalam aspek keadilan dan peningkatan tidak meratanya pendidikan antara kelompok masyarakat dan antar daerah di Indonesia (Aji, 2020).

Pendidikan dapat memberikan bekal bagi kehidupan manusia serta berguna dalam kehidupan bernegara (Roesminingsih \& Susarno, 2011). Selanjutnya dikemukakan bahwa pendidikan mencakup tiga dimensi yang pada akhirnya akan menentukan sifat, nasib dan bentuk individu atau kelompok masyarakat (Nurkholis, 2013). Dengan kedua pendapat ahli tersebut dapat disimpulkan bahwa pendidikan merupakan bagian penting dalam kehidupan manusia yang dapat memberikan bekal ilmu maupun pembentukan karakter individu yang menempuhnya. Pendidikan memiliki berbagai macam tujuan. Salah satunya tujuan pendidikan berperan dalam pengembangan potensi seseorang agar memiliki pengetahuan, sikap dan keterampilan (Rini, 2014). Sedangkan pendapat lain menyatakan bahwa tujuan pendidikan adalah bersifat menuntun (Yanuarti, 2017). Pendidikan dapat menjadi acuan manusia dalam bertindak. Baik dalam bentuk kecerdasan maupun perilaku seseorang. Agar tetap tercapainya tujuan pendidikan, maka pendidikan harus tetap dilaksanakan meskipun dalam kondisi pandemi. Oleh karena itu, adanya surat edaran yang nomor 15 tahun 2020 tentang pedoman penyelenggaraan belajar dari rumah selama pandemi Covid-19 ini (Muhammad, 2020). Tujuan dari adanya surat edaran tersebut yaitu terkait pemutusan rantai penyebaran virus corona dan kegiatan pembelajaran tetap terlaksana.

Kegiatan pembelajaran harus dilaksanakan meskipun tidak berlangsung di sekolah. Solusi yang dapat diterapkan antara lain pembelajaran jarak jauh yang dapat dilaksanakan di rumah. Terdapat suatu anggapan bahwa pelaksanaan pembelajaran jarak jauh dapat mempengaruhi minat belajar siswa (Wulansari \& Manoy, 2020). Dikemukakan bahwa pembelajaran daring di masa pandemi sangat mempengaruhi minat belajar siswa (Yunitasari \& Hanifah, 2020). Tidak menutup kemungkinan bahwa siswa akan merasa bosan saat kegiatan pembelajaran jarak jauh. Hal tersebut sudah menjadi tanggung jawab seorang guru untuk menciptakan pembelajaran yang kreatif dan inovatif (Fitriyani et al., 2021). Sehingga dapat menumbuhkan ketertarikan siswa dalam belajar. Keinginan atau ketertarikan pada kegiatan pembalajaran adalah minat belajar (Sobari, 2017). Adanya minat belajar yang tinggi maka akan berpengaruh terhadap hasil belajar siswa (Berutu \& Tambunan, 2018). Saat ini banyak berbagai platform penunjang pembelajaran online. Salah satunya adalah Learning Management System (LMS). Adanya sarana penunjang tersebut dapat dimanfaatkan sebaik mungkin di masa pembelajaran jarak jauh.

Sistem Manajemen Pembelajaran atau LMS adalah suatu sistem dengan bantuan teknologi yang mengatur kegiatan perencanaan, distribusi, dan evaluasi dalam kegiatan pembelajaran (Limantara \& Jingga, 2014). LMS dapat mewadahi penyampaian materi, pemberian materi, interaksi dan manajemen pembelajaran yang dapat diakses oleh peserta 
didik, administrator dan pembuat materi. Terdapat anggapan bahwa dalam menggunakan LMS dapat meningkatkan hasil belajar siswa (Murni, 2016). Hal tersebut sesuai dengan faktor-faktor yang mempengaruhi keberhasilan dalam belajar antara lain; 1) faktor psikologis, 2) faktor lingkungan masyarakat, 3) faktor lingkungan keluarga, 4) faktor pendukung belajar, dan 5) faktor waktu sekolah (Suwardi, 2012). Terdapat pendapat lain yang mengemukakan faktor-faktor yang mempengaruhi hasil belajar terdiri dari 1) penguasaan praktik mengajar guru, 2) media pembelajaran, 3) penguasaan metode pengajaran, dan 4) motivasi belajar siswa. Ditinjau dari pengertiannya, LMS termasuk ke dalam faktor pendukung kegiatan belajar. Karena LMS dapat digunakan oleh guru dalam pendistribusian media pembelajaran yang terorganisir. Oleh karena itu, kehadiran LMS sangat cocok digunakan ketika pembelajaran jarak jauh guna sebagai pendukung belajar siswa. Pada akhirnya diharapkan dapat meningkatkan hasil belajar siswa.

Hasil belajar adalah suatu evaluasi yang dapat digunakan sebagai acuan dalam menganalisis pencapaian siswa pada kegiatan pembelajaran (Santoso \& Siswanto, 2016). Salah satunya berguna menganalisis sejauh mana siswa memperoleh pengetahuan dari proses pembelajaran yang ditempuhnya. Hasil belajar digolongkan menjadi 3 macam antara lain ranah kognitif, afektif dan ranah psikomotorik (Mulyadi, 2011). Ranah kognitif mencakup pengetahuan siswa, ranah afektif mencakup sikap dan perilaku siswa sedangkan ranah psikomotorik mencakup keterampilan siswa (skill). Penelitian ini membatasi pada hasil belajar dalam cakupan ranah kognitifnya saja. Dikemukakan bahwa dengan menggunakan LMS dapat meningkatkan nilai peserta didik (Pertiwi \& Sumbawati, 2019). Nilai siswa merupakan hasil belajar dalam ranah kognitif siswa karena termasuk dalam kategori pengetahuan. Dapat diungkapkan bahwa penggunaan LMS dalam menunjang kegiatan belajar di masa pandemi.

Berbagai macam model LMS sudah banyak tersedia. Tentunya hal tersebut sangat membantu dalam pelaksanaan kegiatan pembelajara online di masa pandemi. Banyak bermunculan aplikasi LMS seperti salah satunya yaitu google classroom. Aplikasi tersebut sangat mendukung kegiatan belajar mengajar (Nizal et al., 2018). Sesuai dengan pendapat yang menyatakan bahwa google classroom dapat dimanfaatkan pada kegiatan pembelajaran konvensional maupun pembelajaran online (Hapsari \& Pamungkas, 2019). Dalam kondisi pandemi Covid-19 banyak lembaga-lembaga pendidikan yang menggunakannya. Karena google classroom merupakan aplikasi yang dimanfaatkan sebagai LMS yang dapat digunakan kapan dan dimana saja dalam menyampaikan materi-materi pembelajaran (Harefa \& Sumiyati, 2020).

Google classroom merupakan salah satu terbitan google yang banyak digunakan di masa pandemi. Media tersebut dapat diakses secara online dan gratis bagi siapa saja yang memiliki akun google. Google classroom merupakan sebuah alat yang digunakan dalam kegiatan belajar mengajar sehingga diharapkan dapat mempermudah pengajar dalam mengatur setiap penugasan tanpa kertas (Afrianti, 2018). Penelitian lain juga mengemukakan bahwa banyak siswa yang merasa puas dengan pendampingan belajar melalui google classroom (Cristiano \& Triana, 2019). Google classroom memiliki model yang sudah tidak asing lagi bagi siswa karena mereka sudah menggunakan beberapa produk dari google (Katie et al., 2015). Selanjutnya pendapat lain menyatakan bahwa oleh bahwa google classroom efektif digunakan dalam upload tugas, manajemen kelas, dan komunikasi siswa (Azhar \& Iqbal, 2018). Namun, dalam kegiatan pembelajaran google classroom belum memiliki pengaruh yang signifikan. Kehadiran google classroom mempermudah pengumpulan tugas 
namun tetap harus diikuti dengan pendampingan seorang pendidik dalam penjelasan materinya (Puspitasari, 2015). Berdasarkan pendapat tersebut maka dapat disimpulkan bahwa dalam penggunaannya tidak dapat dilepas begitu saja, melainkan perlunya pendidik dalam memberikan ulasan terhadap materi yang sedang diajarkan.

Berdasarkan pengamatan yang telah dilakukan, google classroom banyak digunakan di berbagai jenjang. Dari tingkat perguruan tinggi, sekolah menengah dan bahkan sekolah dasar (SD) juga memanfaatkan media tersebut untuk memenuhi kegiatan belajar. Berdasarkan observasi yang dilakukan oleh peneliti bahwa salah satu sekolah yang memanfaatkan media tersebut adalah SMA Negeri 3 Sidoarjo yang terletak di Kota Sidoarjo Provinsi Jawa Timur. Sekolah tersebut menggunakan google classroom dalam kegiatan pembelajarannya. Dari kelas 10 hingga kelas 12 google classroom digunakan sebagai fasilitas terciptanya kegiatan pembelajaran disana. Google classroom digunakan di semua mata pelajaran. Menurut hasil wawancara peneliti dengan peserta didik kelas 10 IPS bahwa google classroom juga digunakan dalam mata pelajaran ekonomi. Berdasarkan dari beberapa pendapat peserta didik bahwa google classroom digunakan sebagai sarana dalam mata pemberian materi,pembagian tugas dan pengumpulan tugas. Google classroom dapat dikatakan hanya sebagai sarana dalam memberikan materi tidak dalam penjelasan materinya. Selain itu ada juga beberapa pendapat dari peserta didik, bahwa terdapat kesulitan dalam penggunaan google classroom. Seperti kurang stabilnya jaringan internet yang dimiliki masing-masing peserta didik. Sehingga tidak menutup kemungkinan bahwa ada yang mengalami keterlambatan dalam memperoleh informasi yang dibagikan melalui google classroom oleh guru. Namun, ada juga yang mengatakan bahwa google classroom efektif dalam hal pengumpulan tugas dan pembagian materinya yang dapat diakses dengan mudah dan cepat. Dalam google classroom terdapat tenggat waktu pengumpulan tugasnya yang dituliskan oleh guru. sehingga peserta didik diharapkan dapat mengatur waktu secara efektif dalam mengumpulkan tugasnya. Berdasarkan uraian tersebut, tujuan penelitian ini antara lain adalah; 1) Menganalisis pengaruh Learning Management System berbasis google classroom terhadap hasil belajar ekonomi siswa, 2) Menganalisis pengaruh minat belajar terhadap hasil belajar ekonomi siswa, dan 3) Menganalisis pengaruh Learning Management System berbasis google classroom dan minat belajar siswa terhadap hasil belajar ekonomi.

\section{Metode Penelitian}

Penelitian ini menggunakan jenis penelitian kuantitatif dengan metode deskriptif. Populasi dalam penelitian ini adalah seluruh siswa kelas 10 IPS SMA Negeri 3 Sidoarjo. Sedangkan sampel dalam penelitian ini adalah seluruh populasi. Populasi penelitian kurang dari 100 maka pengambilan sampel menggunakan sampel jenuh (Arikunto, 2013). Karena dalam penelitian ini populasi sejumlah 75 orang. Sumber data dalam penelitian ini adalah hasil kuisioner yang disebarkan pada keseluruhan populasi dan data nilai pengetahuan siswa. Untuk menguji adanya keabsahan data penelitian terlebih dahulu dilakukan uji validitas dan reliabilitas instrumen penelitian. Instrumen penelitian untuk mengukur variabel X1 (Google Classroom) disusun berdasarkan sumber dari penelitian (Ernawati, 2018), sedangkan Variabel X2 (Minat Belajar) yang mengadopsi dari penelitian (Sobari, 2017).

Teknik analisis yang digunakan dalam penelitian ini adalah analisis regresi linier berganda. Berikut persamaan regresi linier berganda:

$$
\mathrm{Y}=\mathrm{a}+\mathrm{b} 1 \mathrm{X} 1+\mathrm{b} 2 \mathrm{X} 2
$$



Keterangan:
$\mathrm{Y}$ : variabel terikat
$\mathrm{X}$ : variabel bebas
a : nilai konstanta
b : nilai koefisien regresi

\section{Hasil Penelitian dan Pembahasan}

Berdasarkan penelitian yang telah dilakukan dan disesuaikan dengan tujuan penelitian, berikut dipaparkan data hasil dan pembahasan dari penelitian ini:

1) Efek Learning Management System Berbasis Google Classroom terhadap Hasil Belajar Ekonomi Siswa.

Diketahui bahwa dalam penelitian ini diperoleh hasil terdapat pengaruh yang positif dan signifikan antara LMS berbasis google classroom terhadap hasil belajar ekonomi siswa. Hal tersebut didukung dengan data yang diperoleh dari uji t. Uji t dilakukan untuk menganalisis pengaruh masing-masing variabel bebas secara individu terhadap variabel terikat. Pada penelitian ini diketahui bahwa secara individu LMS berbasis google classroom berpengaruh terhadap hasil belajar ekonomi siswa. berikut data yang digunakan dalam penelitian:

Tabel 1. Hasil Uji t

\begin{tabular}{cc}
\hline Variabel & Uji t (sig) \\
\hline X1 (Google Classroom) & 0,000 \\
X2 (Minat Belajar) & 0,014 \\
\hline
\end{tabular}

Berdasarkan hasil dari tabel tersebut dapat dilihat bahwa nilai dari uji t pada variabel bebas (X1) memiliki nilai signifikansi sebesar 0,000. Artinya bahwa nilai signifikan < 0,05 memiliki arti bahwa terdapat pengaruh variabel dependen terhadap variabel independen.

Selain itu terdapat respon positif dari jawaban yang diberikan responden pada masing-masing item pernyataan antara lain kemudahan akses google classroom, fiturfitur yang ada dalam google classroom, penggunaan google classroom, pengalaman menggunakan google classroom. Sejumlah 15 pernyataan kuisioner yang diberikan kepada responden mayoritas jawaban tertinggi pada opsi setuju. Berikut ini rincian pilihan jawaban setiap item pertanyaan dalam instrument penelitian:

Tabel 2. Persentase Instrumen

\begin{tabular}{cc}
\hline Pilihan & Persentase \\
\hline Sangat tidak setuju & $5,9 \%$ \\
Tidak setuju & $10,6 \%$ \\
Netral & $5 \%$ \\
Setuju & $55 \%$ \\
Sangat setuju & $23,5 \%$ \\
\hline
\end{tabular}

Berdasarkan tabel di atas, dapat diinterpretasikan bahwa terdapat respon atau tangapan yang positif dari responden dengan adanya LMS berbasis google classroom. Adanya respon yang positif yang diberikan oleh responden dapat mengungkapkan bahwa mayoritas responden memberikan kesan yang baik ketika menggunakan google classroom. Dengan adanya respon positif yang diberikan maka tidak menutup kemungkinan bahwa dalam penggunaannya dapat meningkatkan hasil belajar siswa. 
LMS sangat membantu kegiatan pembelajaran daring. Keberadaan LMS dapat menjaga terlaksananya kegiatan pembelajaran.

Hasil dari penelitian ini dapat digunakan untuk memperkuat penelitian terdahulu yang dilakukan oleh (Susanti, 2015). Hasil dari penelitian tersebut mengungkapkan bahwa menggunakan google classroom membuat kegiatan lebih berjalan dengan efektif sehingga dapat meningkatkan hasil belajar siswa dengan syarat tetap memperhatikan faktor lain yang mempengaruhi hasil belajar. Diperoleh hasil uji regresi sebesar 10,7\% dan sisanya adalah 80,3\% dipengaruhi variabel diluar penelitian. Pada penelitian tersebut menggunakan penelitian kuantitatif, namun menggunakan teknik quasi experiment dengan melakukan tes tulis kepada subjek penelitian. Pada penelitian ini, menggunakan jenis penelitian kuantitatif dengan menggunakan uji non tes.

Hasil penelitian ini dapat memperkuat hasil penelitian relevan lain oleh (Edo Arruji, 2020). Hasil penelitian ini menunjukkan bahwa terdapat pengaruh media pembelajaran google classroom terhadap hasil belajar. Terdapat perbedaan antara penelitian ini dengan penelitian terdahulu. Penelitian terdahulu mengemukakan bahwa google classroom berperan sebagai media pembelajaran sedangkan pada penelitian ini google classroom berperan sebagai LMS (Learning Management System). Metode penelitian ini adalah deskriptif analisis sedangkan penelitian sebelumnya menggunakan metode kuasi eksperimen. Pada penelitian sebelumnya terdapat perlakuan pada subjek penelitian dengan adanya kelas kontrol dan kelas eksperimen. Penelitian ini menggunakan instrumen berupa non tes yang disebarkan kepada sejumlah subjek penelitian.

Penelitian ketiga mengungkapkan bahwa terdapat pengaruh google classroom terhadap hasil belajar siswa (Rikizaputra \& Sulastri, 2020). Dalam penelitian ini dikemukakan bahwa dalam menggunakan google classroom dalam kegiatan pembelajaran dapat meningkatkan hasil belajar siswa. Hal tersebut didukung dengan adanya perbedaan nilai N-Gain pada kelas kontrol dan kelas eksperimen. Nilai Ngain pada kelas kontrol sebesar 0,486 sedangkan pada kelas eksperimen sebesar 0,612. Kelas eksperimen menunjukkan nilai hasil belajar yang lebih tinggi dari pada kelas kontrol. Dapat disimpulkan pada penelitian ini menunjukkan hasil yang sama bahwa pengggunaan google classroom berpengaruh terhadap hasil belajar. Penelitian ini dilatar belakangi dengan adanya kemajuan teknologi pada dunia pendidikan sedangkan penelitian ini dilatar belakangi dengan masalah adanya pandemi yang mengharuskan terjadinya pembelajaran jarak jauh dengan memanfaatkan LMS yaitu goggle classroom. Perbedaan lain terletak pada jenis penelitian quasi eksperimen (quasy experimental) sedangkan dalam penelitian ini yaitu penelitian kuantitatif. Data pada penelitian sebelumnya diperoleh dengan teknik the matching only pretest posttest control group sedangkan pada penelitian ini adalah dengan instrumen non tes. Instrumen penelitian tersebut dengan menyebarkan sejumlah 30 soal pilihan ganda sedangkan penelitian ini dilakukan penyebaran kuisioner kepada sejumlah responden penelitian.

2) Efek Minat Belajar terhadap Hasil Belajar Ekonomi Siswa.

Diketahui bahwa dalam penelitian ini diperoleh hasil terdapat pengaruh yang positif dan signifikan pada minat belajar siswa terhadap hasil belajar ekonomi siswa. Hal tersebut didukung dengan data yang diperoleh dari uji t. Uji t dilakukan untuk 
menganalisis pengaruh masing-masing variabel bebas secara individu terhadap variabel terikat. Pada penelitian ini dikethui bahwa secara individu antara minat belajar siswa berpengaruh terhadap hasil belajar ekonomi siswa. berikut data yang digunakan dalam penelitian:

Tabel 3. Hasil Uji t

\begin{tabular}{cc}
\hline Variabel & Uji t (sig) \\
\hline X1 (Google Classroom) & 0,000 \\
X2 (Minat Belajar) & 0,014 \\
\hline
\end{tabular}

Berdasarkan hasil dari tabel tersebut dapat dilihat bahwa nilai dari uji t pada variabel bebas (X2) memiliki nilai signifikansi sebesar 0,014. Artinya bahwa nilai signifikan < 0,05 memiliki arti bahwa terdapat pengaruh variabel dependen terhadap variabel independen. Sehingga diperoleh temuan bahwa terdapat pengaruh positif dan signifikan antara minat belajar (X2) terhadap hasil belajar (Y).

Selain itu terdapat respon positif dari jawaban yang diberikan responden pada masing-masing item pernyataan antara lain antusiasme peserta didik mengikuti pembelajaran, persiapan peserta didik dalam mengikuti pembelajaran, apresiasi peserta didik terhadap kegiatan pembelajaran, respon peserta didik ketika proses pembelajaran. Berdasarkan item tersebut yang disusun menjadi 15 pernyataan kuisioner yang diberikan kepada responden mayoritas jawaban tertinggi pada opsi setuju. Berikut adalah ringkasan tabel dari kuisioner:

Tabel 4. Persentase Hasil Instrumen

\begin{tabular}{cc}
\hline Pilihan & Tingkatan \\
\hline Sangat tidak setuju & $5 \%$ \\
Tidak setuju & $20 \%$ \\
Netral & $23,8 \%$ \\
Setuju & $40 \%$ \\
Sangat setuju & $6,2 \%$ \\
\hline
\end{tabular}

Berdasarkan tabel di atas, dapat diinterpretasikan bahwa angka terbesar diperoleh pada opsi setuju sebesar $40 \%$, netral 23,8\%, tidak setuju 20\%, sangat setuju sebesar $6,2 \%$ dan sangat tidak setuju sebesar 5\%. Hal tersebut menunjukkan bahwa adanya respon yang positif yang diberikan oleh responden dapat mengungkapkan bahwa mayoritas responden setuju bahwa minat belajar dapat mempengaruhi hasil belajar siswa. Sangat penting membangun minat belajar ketika pelaksanaan pembelajaran jarak jauh. Dengan begitu hasil belajar siswa akan tetap membaik meskipun pembelajaran tidak secara bertatap muka.

Hal tersebut memperkuat penelitian sebelumnya yang dilakukan oleh (Fitrianingrum, 2017) yang menyatakan bahwa adanya pengaruh minat belajar terhadap hasil belajar. Perbedaan antara penelitian ini dan penelitian sebelumnya terdapat pada teknik analisis yang digunakan. Dimana penelitian sebelumnya menggunakan teknik analisis regresi linier sederhana sedangkan penelitian ini menggunakan teknik analisis regresi berganda. Pada penelitian sebelumnya hanya terdapat satu variabel bebas yaitu minat belajar (X1). Sedangkan penelitian ini menggunakan dua variabel bebas antara lain google classroom (X1) dan minat belajar (X2). Terdapat perbedaan tujuan penelitian ini dengan penelitian sebelumnya. Penelitian sebelumnya bertujuan untuk menganalisis pengaruh minat belajar terhadap 
hasil belajar. Penelitian ini bertujuan untuk menganalisis secara bersama-sama pengaruh LMS berbasis google classroom dan minat belajar terhadap hasil belajar siswa.

Penelitian lain yang relevan sehingga dapat memperkuat penelitian ini oleh (Firmansyah, 2015). Hasil dari penelitian terdahulu adalah terdapat pengaruh minat belajar terhadap hasil belajar siswa. Kedua penelitian ini memiliki persamaan dalam tujuan penelitian untuk menganalisis efek minat belajar terhadap hasil belajar. Persamaan lain adalah pada teknik analisis yaitu keduanya menggunakan teknik analisis regresi linier berganda. Kedua penelitian ini memiliki 2 variabel bebas (X). Penelitian sebelumnya menggunakan variabel strategi pembelajaran (X1) sedangkan penelitian ini menggunakan variabel google classroom (X1). Pada variabel X2 keduanya menggunakan variabel minat belajar. Tedapat perbedaan pada metode penelitian. Penelitian sebelumnya menggunakan metode eksperimen sedangkan penelitian ini menggunakan metode kuantitatif dengan analisis deskriptif. Penelitian tersebut menggunakan kelas eksperimen dan kelas kontrol untuk diberikan perlakuan. Instrumen yang digunakan berupa intrumen tes dan penelitian ini menggunakan instrumen non tes.

Penelitian selanjutnya yang relevan yang dilakukan oleh (Pangestu et al., 2015). Persamaan penelitian ini dengan penelitian sebelumnya untuk menganalisis pengaruh minat belajar terhadap hasil belajar siswa. Hasil penelitian sebelumnya mengemukakan bahwa terdapat pengaruh positif signifikan antara minat belajar terhadap hasil belajar siswa dengan kontribusi sebesar $15,1 \%$. Penelitian ini memiliki hasil bahwa terdapat pengaruh minat belajar siswa secara positif dan signifikan terhadap hasil belajar dengan kontribusi sebesar 19,2\%. Pengambilan sampel penelitian dilakukan dengan teknik proportional random sampling sedangkan sampel penelitian ini menggunakan sampel jenuh. Persamaan keduanya menggunakan instrumen penelitian berupa non tes. Penelitian sebelumnya menggunakan teknik analisis regresi linier sederhana sedangkan penelitian ini menggunakan teknik analisis regresi linier berganda.

3) Efek Learning Management System Berbasis Google Classroom dan Minat Belajar terhadap Hasil Belajar Ekonomi Siswa.

Setelah dilakukan uji F maka diketahui bahwa terdapat pengaruh secara simultan LMS berbasis google classroom dan minat belajar terhadap hasil belajar ekonomi siswa. Tujuan dilakukan uji $\mathrm{F}$ adalah untuk menganalisis pengaruh bersama-sama antara variabel bebas terhadap variabel terikat. Variabel bebas dalam penelitian ini antara lain LMS berbasis google classroom (X1) dan minat belajar (X2) sedangkan variabel terikat yaitu hasil belajar (Y). Di bawah ini adalah ringkasan tabel uji $\mathrm{F}$ melalui uji regresi linier berganda:

\section{Tabel 5. Uji F}

\begin{tabular}{cc}
\hline Uji & Sig \\
\hline Uji F & 0,000 \\
\hline
\end{tabular}

Interpretasi dari tabel di atas adalah bahwa ditemukan pengaruh simultan LMS berbasis google classroom dan minat belajar terhadap hasil belajar ekonomi siswa. ditemukan nilai signifikansi sebesar 0,000. Memiliki arti bahwa nilai signifikansi < 0,05 . Maka hipotesis dalam penelitian ini diterima yang artinya terdapat pengaruh simultan antara variabel bebas dan variabel terikat. LMS berperan penting di masa 
pandemi seperti saat ini. Dengan keberadaan LMS maka kegiatan pembelajarn tetap dapat terlaksana. Namun sebagai pendidik tentu harus tetap menciptakan suasana yang tidak membosankan agar minat siswa untuk belajar dapat meningkat. Sehingga dapat tercipta hasil belajar yang maksimal.

Berdasarkan hasil tersebut dapat memperkuat penelitian sebelumnya yang dilakukan oleh (Sirait \& Apriliyani, 2021) yang mengemukakan bahwa terdapat pengaruh interaktif yang signifikan antara media pembelajaran google classroom dan minat belajar terhadap hasil belajar matematika siswa. Persamaan penelitian ini dengan penelitian sebelumnya terletak pada variabel bebas (X1 dan X2) dan variabel terikat (Y). Keduanya memiliki variabel bebas google classroom dan minat belajar. Pada variabel terikat keduanya menggunakan hasil belajar. Terdapat perbedaan bahwa penelitian sebelumnya mengemukakan bahwa google classroom sebagai media pembelajaran sedangkan penelitian ini mengemukakan bahwa google classroom sebagai LMS (Learning Management System). Metode penelitian sebelumya menggunakan metode eskperimen sedangkan penelitian ini menggunakan kuantitatif dengan analisis deskriptif. Perbedaan selanjutnya terdapat pada teknik analisi penelitian. Penelitian ini menggunakan teknik analisis regresi linier berganda sedangkan penelitian sebelumnya menggunakan teknik analisis dua jalur.

Penelitian lain yang dapat memperkuat hasil penelitian ini yang dilakukan oleh (Faturohmi, 2020). Hasil dari kedua penelitian ini memiliki perbedaan bahwa penelitian sebelumnya mengemukakan terdapat pengaruh yang tidak signifikan antara media pembelajaran google classroom dan minat belajar terhadap hasil belajar siswa. Pada penelitian ini menyatakan bahwa terdapat pengaruh yang signifikan antara LMS berbasis google classroom dan minat belajar terhadap hasil belajar siswa. Penelitian sebelumnya mengemukakan bahwa google classroom berperan sebagai media sedangkan penelitian ini mengungkapkan bahwa google classroom adalah LMS (Learning Management System). Metode penelitian sebelumnya menggunakan survey dengan pendekatan kuantitatif. Penelitian ini menggunakan metode analisis deksriptif dengan pendekatan kuantitatif. Teknik analisis penelitian sebelumnya menggunakan teknik MRA (Moderated Analysis Regression) sedangkan penelitian ini menggunakan teknik analisis regresi linier berganda. Instrumen penelitian keduanya menggunakan kuisioner, namun pada penelitian sebelumnya juga menggunakan instrumen tes.

\section{Kesimpulan}

Kesimpulan yang diperoleh dari hasil penelitian ini antara lain adalah; 1) Terdapat pengaruh positif dan signifikan antara Learning Management System berbasis google classroom terhadap hasil belajar ekonomi siswa, 2) Terdapat pengaruh positif dan signifikan antara minat belajar terhadap hasil belajar ekonomi siswa, dan 3) Secara bersama-sama bahwa Learning Management System berbasis google classroom dan minat belajar berpengaruh terhadap hasil belajar ekonomi siswa.

\section{Saran}

Saran yang dapat disampaikan berdasarkan hasil penelitian ini adalah bagi guru di seluruh jajaran satuan pendidikan sebaiknya memanfaatkan keberadaan Learning Management System (LMS) saat pembelajaran jarak jauh. Salah satunya dapat memanfaatkan google classroom sebagai penunjang pembelajaran. Dimana google classroom dapat digunakan 
untuk mengorganisir kegiatan pembelajaran. Menuangkan kreatifitas guru saat menggunakan google classroom agar pembelajaran tidak membosankan. Pada akhirnya dapat menumbuhkan minat belajar siswa. Menumbuhkan minat peserta didik juga merupakan salah satu hal penting di masa-masa seperti ini.

\section{Daftar Pustaka}

Afrianti, W. E. (2018). PENERAPAN GOOGLE CLASSROOM DALAM PEMBELAJARAN AKUNTANSI.

Aji, R. H. S. (2020). Dampak Covid-19 pada Pendidikan di Indonesia. Jurnal Sosial \& Budaya Syar-I, 7(5), 10. https://doi.org/10.15408/sjsbs.v7i5.15314

Arikunto, S. (2013). PROSEDUR PENELITIAN: SUATU PENDEKATAN PRAKTIK. Rineka Cipta.

Azhar, K. A., \& Iqbal, N. (2018). EFFECTIVENESS OF GOOGLE CLASSROOM: TEACHERS '. Journal of Soscial Knowledge Prizren, 2(2), 52-66.

Berutu, M. H. A., \& Tambunan, M. I. H. (2018). Pengaruh Minat dan Kebiasaan Belajar Terhadap Hasil Belajar Biologi Siswa. Jurnal Penelitian Pendidikan, 1(2), 12.

Cristiano, K., \& Triana, D. (2019). Google classroom as a tool-mediated for learning. Journal of Physic : Conference Series. https://doi.org/10.1088/1742-6596/1161/1/012020

Edo Arruji. (2020). Pengaruh Media Google Classroom Terhadap Hasil Belajar Pada Konsep Sistem Gerak. Jurnal Ilmu Pendidikan, 5(2).

Ernawati. (2018). Pengaruh Penggunaan Aplikasi Google Classroom Terhadap Kualitas Pembelajaran dan Hasil Belajar Siswa Pada Mata Pelajaran Ekonomi Kelas XI Di MAN 1 Tangerang Selatan. Universitas Islam Negeri Syarif Hidayatullah.

Faturohmi, R. (2020). Pengaruh Media Pembelajaran Google Classroom Terhadap Hasil Belajar dengan Minat Belajar sebagai Variabel Moderator. Jurnal Pendidikan, 7(2).

Firmansyah, D. (2015). Pengaruh Strategi Pembelajaran dan Minat Belajar terhadap Hasil Belajar Matematika. Jurnal Pendidikan, 7(1).

Fitrianingrum, L. (2017). Pengaruh Minat Belajar terhadap Hasil Belajar Mata Pelajaran Ilmu Pengetahuan Alam Siswa Kelas V MI Muhammadiyah Karanglo. Pendidikan IPA, $5(3)$.

Fitriyani, Y., Fauzi, I., \& Sari, M. (2020). Motivasi Belajar Mahasiswa Pada Pembelajaran Daring Selama Pandemik Covid-19. Jurnal Kependidikan: Jurnal Hasil Penelitian dan Kajian Kepustakaan di Bidang Pendidikan, Pengajaran dan Pembelajaran, 6(2), 165-175. doi:https://doi.org/10.33394/jk.v6i2.2654

Hapsari, S. A., \& Pamungkas, H. (2019). Pemanfaatan google classroom sebagai media pembelajaran online di universitas dian nuswantoro. WACANA, 18(2), 225-233.

Harefa, N., \& Sumiyati. (2020). Persepsi Siswa terhadap Google Classroom sebagai LMS pada masa Pandemi Covid-19. Pendidikan Unisla, 2(2). https://doi.org/http://jurnalpendidikan.unisla.ac.id/index.php/SEAJ

Katie, L., Izenstark, \& Amanda. (2015). Google Classroom for Librarians: Features and Opportunities. 3, 369-381. 
Limantara, N., \& Jingga, F. (2014). Perancangan Model Learning Management System untuk Sekolah. Computer, Mathematics and Engineering Application, 5(1), 203-212. https://doi.org/https:// doi.org/10/.21512/comtech.v5i1.2610

Muhammad, H. (2020). Pedoman Penyeleggaraan Belajar dari Rumah.

Mulyadi. (2011). Evaluasi Pendidikan dan Pengembangan Model Evaluasi Evaluasi Pendidikan Agama. UIN Maliki Press.

Murni, C. K. (2016). Pengaruh E-Learning Berbasis Schoology Terhadap Peningkatan Hasil Belajar Siswa Dalam Materi Perangkat Keras Jaringan Kelas X. Infromation Technology and Education, 1(01). https://ejournal.unesa.ac.id

Nizal, I., Shaharanee, M., Jamil, J. M., Syamimi, S., \& Rodzi, M. (2018). The Application of Google Classroom as a Tool for Teaching and Learning. Telecomunication, Electronic Adn Computer Engineering, 8(10), 8-11.

Nurkholis. (2013). PENDIDIKAN DALAM UPAYA MEMAJUKAN TEKNOLOGI. Jurnal Kependidikan, 1(1), 24-44.

Pangestu, A. D., Samparadja, H., \& Tya, K. (2015). Pengaruh Minat Terhadap Hasil Belajar Matematika. Jurnal Penelitian Pendidikan Matematika, 3(2).

Pertiwi, F. T., \& Sumbawati, M. S. (2019). Pengaruh Penggunaan Learning Management System Berbasis Chamilo dan Motivasi Terhadap Hasil Belajar Siswa SMK Kelas X. Information Technology Ad Education, 3(02). https://ejournal.unesa.ac.id/index.php/it-edu/article/view/27029

Puspitasari, I. (2015). Efektivitas Google Classroom. www.lpminsitut.com

Rikizaputra, \& Sulastri, H. (2020). Pengaruh E-Learning dengan Google Classroom terhadap Hasil Belajar dan Motivasi Belajar Siswa. Pendidikan, 11(1). https://doi.org/https://doi.org/10.31849/lectura.v1i1.3760

Rini, Y. S. (2014). Hakikat, Tujuan dan Proses Pendidikan. Pendidikan.

Roesminingsih, \& Susarno, L. H. (2011). Teori dan Praktek Pendidikan (Sugiono (ed.); 8th ed.). Bintang Surabaya.

Rozi, F., Rahma Safitri, S., Latifah, I., \& Wulandari, D. (2021). Tiga Aspek dalam Pembelajaran Pendidikan Jasmani pada Masa Pandemi Covid-19. Jurnal Kependidikan: Jurnal Hasil Penelitian dan Kajian Kepustakaan di Bidang Pendidikan, Pengajaran dan Pembelajaran, 7(1), 239-246. doi:https://doi.org/10.33394/jk.v7i1.3220

Santoso, V. L. P., \& Siswanto, B. T. (2016). FAKTOR-FAKTOR YANG MEMPENGARUHI HASIL BELAJAR SISWA PADA PEMBELAJARAN SMK DI YOGYAKARTA. Pendidikan Vokasi, 6(1), 111-120. http://journal.uny.ac.id

Sirait, E. D., \& Apriliyani, D. D. (2021). Pengaruh Media Pembelajaran Google Classroom dan Minat Belajar Terhadap Hasil Belajar Matematika. Jurnal Pendidikan Dan Teknologi, 5(2), 10-11.

Sobari, F. (2017). Pengaruh Minat Belajar Terhadap Hasil Belajar Siswa Pada Mata Pelajaran Ilmu Pengetahuan Sosial. Kependidikan, 3(2), 8. 
Susanti, L. (2015). HUBUNGAN PENGGUNAAN GOOGLE CLASSROOM SEBAGAI PEMBELAJARAN EFEKTIF DAN PAPERLESS TERHADAP NILAI HASIL BELAJAR KOGNITIF PADA PELAJARAN BIOLOGI DI SMA CHARISMALANG. Inovasi Pendidikan Di Era Biodata Dan Psikologinya, 3, 253-258.

Suwardi, D. R. (2012). FAKTOR-FAKTOR YANG MEMPENGARUHI HASIL BELAJAR SISWA. Economic Education Analysis Journal, 1(2). http://journal.unnes.ac.id/sju/index.php/eeaj

Wulansari, N. H., \& Manoy, J. T. (2020). Pengaruh Motivasi dan Minat Belajar Siswa Terhadap Prestasi Belajar Matematika Selama Study at Home. Jurnal Penelitian $\begin{array}{lllll}\text { Pendidikan Matematika Dan } & \text { Sains, }\end{array}$ https://doi.org/http://dx.doi.org/10.26740/jppms.v4n2.p72-81

Yanuarti, E. (2017). Pemikiran Pendidikan Ki Hajar Dewantara dan Relevansinya Dengan Kurikulum 13. Jurnal Penelitian, 11(2), 239.

Yunitasari, R., \& Hanifah, U. (2020). Pengaruh Pembelajaran Daring terhadap Minat Belajar Siswa pada Masa COVID 19. Jurnal Ilmu Pendidikan, 2(3), 8. 